\title{
Transposition
}

Musique et Sciences Sociales

\section{"I don't give a shit where I spit my phlegm" (Tribe 8). Rejection and Anger in Queer-Feminist Punk Rock}

\section{Maria Katharina Wiedlack}

\section{(2) OpenEdition}

\section{Journals}

Electronic version

URL: http://journals.openedition.org/transposition/280

DOI: $10.4000 /$ transposition.280

ISSN: 2110-6134

Publisher

CRAL - Centre de recherche sur les arts et le langage

\section{Electronic reference}

Maria Katharina Wiedlack, «"I don't give a shit where I spit my phlegm" (Tribe 8). Rejection and Anger in Queer-Feminist Punk Rock », Transposition [Online], 3 | 2013, Online since 01 March 2013,

connection on 20 April 2019. URL : http://journals.openedition.org/transposition/280 ; DOI : 10.4000/ transposition.280

This text was automatically generated on 20 April 2019.

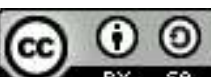

La revue Transposition est mise à disposition selon les termes de la Licence Creative Commons Attribution - Partage dans les Mêmes Conditions 4.0 International. 


\title{
"I don't give a shit where I spit my phlegm" (Tribe 8). Rejection and Anger in Queer-Feminist Punk Rock
}

\author{
Maria Katharina Wiedlack
}

1 The statement and title for my article, ${ }^{1}$ "I don't give a shit where I spit my phlegm", is part of the lyrics to the song "People Hate Me" by the band Tribe 8, which is - as will be explained later on - an excellent example of queer-feminist politics of a punk rock band. This article focuses on queer-feminist punk - also known as queercore, homocore or dykecore - music, its lyrics as well as performances and sound. It focuses on punk music as a form of queer-feminist activism and agency.

2 The examples of punk rock performers and their cultural productions that I present here will be understood as forms of queer politics and queer theory as well as feminist theory. The usage of the terminology of queer-feminist politics - rather than queer politics - is inspired by the tradition of many activists around the world who have been foregrounding the feminist aspects of their queer politics for many years. More recently similar politics found their way into academic accounts for example through the book "Feminism is Queer: The Intimate Connection between Queer and Feminist Theory" by Mimi Marinucci, the work of José Muñoz, ${ }^{2}$ Judith "Jack" Halberstam, ${ }^{3}$ and others. Such activist and academic accounts alike understand queer politics as a continuation of feminist movements and theory rather than as a revolutionary break with it. Furthermore, such accounts seek a dialogue between lesbian and gay movements, second wave feminists and the diverse range of queer movements to build alliances and forms of solidarity. Considering the concrete example of queer-feminist punk rock, I argue that especially female identified or perceived persona seek to find alliances with different groups of feminist thinkers and activists. They and their allies understand the usefulness of feminist politics, activist strategies and social analysis against the - often racialized misogyny of mainstream culture as well as the countercultural environments of punk rock and queer scenes. 
However, queer-feminist punk musicians and writers combine feminist accounts with their specific punk philosophy of anti-social queerness or queer negativity. Analyzing lyrical content - its meanings, its rhetoric, or tone - I will not only show examples of queer-feminist anti-social accounts of punk music like expressions of negativity and anger, but also argue that queer-feminist punk rock as such can be understood as politics of negativity. Relating such queer-feminist punk negativity to academic concepts and scholarly work, I aim to show how punk rock is capable of communicating queer-feminist theoretical positions in a non-academic setting, following scholars such as Judith "Jack" Halberstam, ${ }^{4}$ José Muñoz, ${ }^{5}$ or Angela Wilson. ${ }^{6}$

One of the first queer-feminist punk rock accounts was a very provocative article by the musician, script writer, film- and theater-director Bruce LaBruce and artist, filmmaker, musician, and zine-editer G.B. Jones in April 1989 edition of the widely distributed punk magazine "Maximumrocknroll", which brought queercore or homocore into focus within the broader US hardcore punk scene. In their article Jones and LaBruce criticize the hardcore punk scene harshly for its misogyny, homophobia and sexism as well as the gay and lesbian club culture for its shallowness. They develop a humorous argumentation about the intersections of punk and homosexuality, with the intention to provoke the hardcore punk scene. One example of their ironic take is the introduction of a dictionary entry for the word punk, emphasizing its former usage to describe homosexuals as well as prisoners. The passage explains that

[...] punk is also an archaic word for dried wood used as tinder, the original meaning of the word "faggot" as well. Homosexuals, witches, criminals, all denounced as enemies of the state, were once burned at the stake. The word for the material used to set them on fire became another name for the victims themselves. ${ }^{7}$

The absence of note on the resource this explanation came from and the general ironic tone of the article allows for multiple interpretations. In addition to emphasizing the sexual qualities and meanings of the word "punk" they draw attention to the anti-social meanings of the word "queer"; their politics seem simultaneously a queering of punk and a "punking" of queer. This queering and punking, however, produces ambivalent meanings and can be interpreted equally as sarcasm and/or sincerity.

Following Jones' and LaBruce's approach queercore punks like the band Tribe 8 started producing provocative and humorous punk music. Especially female-bodied bands like Tribe 8, or bands with female-bodied and female-identified musicians like God Is My CoPilot redefined the term queer to appropriate it for their politics, criticizing the male dominance within the hardcore punk scene as well as the gay and lesbian scenes, which seemed to them one-dimensional, superficial, and segregated. Accordingly, the term queer does not simply substitute for the terms "gay" or "lesbian", but rather it represents a more open and critical understanding of queer, including ambivalence and critique towards fixed identity categories. Again it needs to be emphasized that an important quality of such appropriations is humor, as this quote from the zine "Homocore NYC" from 1994 shows:

This is what [queer] means: Lesbian, Gay, Bisexual. [...] includ[ing] Bicycles as well as Dykes and Fags [which] comes from its universal use, as helpfully playground? Or was it in gym class? who said to me: if you fuck men, you're not a fucking Queer. [...] or a fucking woman. Obviously, another citation will be required to include usage referring to Lesbians.

7 In this passage, the editor of Homocore NYC and band-member of God Is My Co-Pilot ${ }^{8}$ Craig Flanagin refers in an unserious, playful way to an understanding of queer as similar 
to what Eve Kosofsky Sedgwick has phrased "the open mesh of possibilities, gaps, overlaps, dissonances and resonances, lapses and excesses of meaning when constituent elements of anyone's gender, of anyone's sexuality aren't made (or can't be made) to signify monolithically."9 The humorous language, in which his definition appears, moreover, can be understood as cultural translation of a critical queer theory concept into a language his fellow punk peers could relate to.

In addition to its fluid character, queer in queer-feminist punk lyrics and other forms of writing often reverts to the primary quality of the word, that is, pejorative. Attention is drawn to the "anarchic character to the word queer", ${ }^{10}$ its anti-social character. Thus, queer-feminist punk rock anticipated what queer theorists like Judith "Jack" Halberstam call the "Anti-Social Turn in Queer Studies". ${ }^{11}$ This theoretical approach is grounded in a psychoanalytical Lacanian understanding of sexuality which posits that, "[r]ather than a life-force connecting pleasure to life, survival and futurity, sex, and particularly homosex and receptive sex, is a death drive that undoes the self [...]."12

9 A decade after the initiation of an emancipatory usage of the term queer, anti-social queer theory academics and activism echoed this initial motive, taking up psychoanalytical concepts of sexuality. Crucial for the extensive work on anti-social queer theory done since then, was Leo Bersani's 1995 publication Homos. Following queer psychoanalytical approaches, Leo Bersani suggested in his book, that sex in general and homosex in particular, needs to be understood as anti-communicative, anti-identitarian, and destructive (see Bersani 1995): "the value of sexuality itself [...] is to demean the seriousness of efforts to redeem it." ${ }^{13}$

The theorist, who most significantly influenced this discourse which understands queer as a negative, anti-social term, beyond boarders and disciplines, during the last couple of years was Lee Edelman with his book No Future: Queer Theory and the Death Drive. Taking up Bersani's suggestion of an understanding of the sexual instinct, to be distinguished from sexual desire, as such as converging force towards the destruction of the self - framed by psychoanalysis as the death drive - Edelman argues that sexuality can only be 'saved' from its self-destructing and irritating qualities, and integrated into the symbolic order, by attaching its meaning and purpose to reproduction. One effect and certainly a consequence of this 'rescue project' is that queer in this logic can only signify the opposite of creation and reproduction "the place of the social order's death drive."14 Interwoven with sexuality's cultural meaning of reproduction is the concept of "futurity". The future of society, which is the meaning and goal of every political action, according to Edelman, is always visualized through the imaginary "Child". ${ }^{15}$ Therefore "the queer subject, [...] has been bound epistemologically to negativity, to nonsense, to antiproduction, to unintelligibility [...]."16

11 Queer-feminist punk lyrics, as the following example of the early 1990s punk outfit God Is My Co-Pilot shows, used the same language as Edelman does in his famous book years before Edelman did himself, for example when they sing "We're here we're queer we're going to fuck your children" (God Is My Co-Pilot, Queer Disco). Some passages of Edelman's work sound very similar in comparison, for example this often quoted paragraph:

Fuck the social order and the Child in whose name we're collectively terrorized; fuck Annie; fuck the waif from Les Mis; fuck the poor innocent kid on the Net; fuck Laws both with capital Ls and with small; fuck the whole network of Symbolic relations and the future that serves as its prop. ${ }^{17}$ 
12 analyzed, such embracing of negativity, here demonstrated in the word "queer", is not only significant for queer-feminist punk rock, but also organic to for the genre of punk rock itself. Punk rock emerged as aggressive anti-social, anti-authoritarian "statement" from the perspective of a disadvantaged youth and has ever since connoted anti-social rebellion. THE signifier for the rejection of society and its norms was "No Future", first uttered by the Sex Pistols in God Save The Queen, influencing generations of punks. Interestingly, the theorist best known for anti-social queer theory today, Lee Edelman, used this punk phrase as the title for his popular book No Future. Although, he rejected Halberstam's linkage between his book's title and punk's central phrase, the link is nevertheless meaningful.

An additional link between punk and queer can be seen in the fact, that sexual, cultural and ethnic minorities have been part of punk scenes from its beginning on. ${ }^{20}$ The rejection of society from the standpoint of an oppressed or outcast group and the affirmation of this negative status as performed through punk rock, inspired the specific subcultural and political movement, which established punk rock. This affinity of queers to the genre punk was not unconscious or accidental. On the contrary, queer punks shared a detailed knowledge of the emergence, politics and performativities of the early punk scenes. In the same Maximumrocknroll article mentioned before, LaBruce and Jones explain in quite some detail what and whose gender and sexual politics among the old punks attracted them. They mention Siouxie and the Banshees' lyrics about lesbian love, they praise X-Ray-Spex, The Raincoats, and The Slits as examples for women fighting rigid gender roles and mention The Nervous Gender's and the Dick's gender-bending performances.

On the one hand, the "queer-reading" by LaBruce and Jones of first-generation punk bands needs to be understood as self-legitimization by punks. Showing their detailed knowledge about punk bands was intended to signal to their hardcore punk peers forms of belonging to their scenes and culture. Additionally, such queering of some of the scenes' most appreciated reference figures is a form of provocation. Nevertheless, describing the gender-critical and sexual liberating attitudes of early punk and reading them in reference to the derogatory meanings of punk and queerness, is also a statement towards the queer community about queer activism. Against common forms of lesbian and gay discourse advocating tolerance and inclusion, queer-feminist punks strongly embrace the outsider-status and argue for the usage of aggression, outspoken anti-social behavior, and a liberating verbal (or non-verbal) violation of rules.

\section{"Not gay as in happy, but queer as in fuck you"21 - negativity and/in anti-social lyrics}

15 It needs to be emphasized again, that the experience of homophobia and hatred against non-normative individuals and groups addressed with the word queer were the reasons for queer activists as well as queer theorists to take up the term in the first place, as already mentioned in relation to the affinities between the terms and the concepts queer and punk. When Queer Nation decided to use the term queer, they did because it was "the most popular vernacular term of abuse for homosexuals." 22 To use queer for queer activists was "a way of reminding [queers] how [they] are perceived by the rest of the 
world." ${ }^{23}$ Taking up the term queer was a provocation: provocation towards assimilationist and identitarian gay and lesbian politics as well as a form of activism against homophobia. The aim was not to win support or approval by heteronormative hegemony, but rather to stage a rejection of a civil rights model of political activity, fighting for equal rights for an oppressed minority. ${ }^{24}$

Accordingly, Tribe 8's aforementioned "I don't give a damn where I spit my phlegm" from their song "Neanderthal dyke" or Agatha's constantly repeated slogan "Not gay as in happy, but queer as in fuck you" from their 2009 recorded song "queer as in fuck you" on their album "Panic Attack" can be read as anti-social behavior and a verbalization of critique, with a definitive political focus.

\section{Queer-feminist punk - enchante provocateure within punk rock and feminist circles}

Such anti-socially verbalized critique is often, as mentioned, not only directed against an undefined or general mainstream, but addresses other 'progressive' scenes like hardcore punk communities, or - in the case of the lesbian-only band Tribe 8 - the lesbian separatist scene of the 1990s.

Indeed, Tribe $8^{25}$ became famous especially within the queercore scene and in feminist circles, due to their fiercely contested shows and lyrics. What made their songs so provocative can be demonstrated according to their already quoted song "Neanderthal dyke" on their 1995 album "Fist City", which was released by Alternative Tentacles. In the song, Tribe 8 comment in their very undiplomatic way on the politics of the Michigan Womyn's Music Festival ${ }^{26}$ and the radical feminist scene, which regularly organizes and frequents, based on their experience of playing at the festival in 1994. "My political consciousness is fried, I'm not exactly woman identified, I don't give a shit, I just wanna get laid by curvy little hot and sexy eyeliner babes", the singer Lynn Breedlove states in the song. Breedlove's usage of feminists' language like "political consciousness", or "woman identified", signals that the intended target of the song is feminists, concretely the lesbian separatist scene, and can be further understood as attempt to mock them through imitation. The title and theme of the song "Neanderthal dyke / neanderthal dyke", need to be understood as a clear critique of the lesbian separatist scene's lack of reflexivity about middle class privileges, their blindness to their boundaries and exclusiveness. Similar critique appears in the final part of the song: "Feminists theory gives me a pain, besides I think you like the fact I'm low on the food chain, don't you." The lines "never read McKinnon / I ride a big bike / feminist gets me uptight / get in some heels and lipstick and I'll spend the night", additionally serve as an indictment of overly rigid feminist understandings of the terms "women" and "lesbian". The line "Did it play at Michigan, is it correct?", which addresses the annual Michigan Womyn's Music Festival and the mentioning of the anti-pornography feminist Catharine McKinnon signals again a particular brand of feminism as the song's addressee.

The frequent usage of lines addressing sexual intercourse, like "I'll spend the night", as well as the lines "Pseudo intellectual slut / you went to school did you learn how to fuck?" are a statement against some feminists but also the prudery of the American mainstream. Moreover, such lyrics can be seen as a re-signification of queerness, queer theory and queer punk as sexually connoted. 

song "queer as in fuck you" seems worthwhile. In their song - which was written more then fifteen years after Tribe 8's "Neanderthal dyke" - queer indeed carries the already mentioned negative but also a very multifarious (sexual) connotation. Agatha certainly sing about queer as political activism and action, but it seems to be of great importance to also reconnect queer with deviant sexualities, to make queer sexy and dirty again, probably against the neoliberal appropriation of queer as a term for a fashionably gay lifestyle. The "fuck you", of course needs to be understood as an offensive anti-social gesture and rejection first of all. Additionally, however, it means sexual intercourse. Such an interpretation becomes visibly suggested in combination with the line "I wanna sing about liberation but I can't do that without talking about your lips", ${ }^{27}$ which can denote the lips of a mouth, but also the lips of a vulva. All those double connotations and meanings reflect on the term queer, which is key within the lyrics, and in turn makes all the other lyrics meaningful in Agatha's specific queer-feminist context. "Queer" within the lyrics, in other words, draws on all these connotations and questions the subcultural meaning and usage of the term "queer" as such.

21 Many queer-feminist punk rock lyrics play with language and meanings, and their audience's interpretations, like the previous examples by Tribe 8 , or Agatha. The male cis-gendered-only band Pansy Division, ${ }^{28}$ for example, play with double meanings in the first few lines of their song "Smell's Like Queer Spirit", a cover-version of Nirvana's "Smells Like Teen Spirit", when they sing "Against all odds, we appear / Grew up brainwashed, / But turned out queer / Bunsplitters, rugmunchers too / We screw just how we want to screw / Hello, hello, hello, homo." "Screw", here, can mean to fail at something, but additionally it can mean to have sex with somebody. The latter interpretation is especially obvious in the very explicitly sexual following lines: "With the lights out, it's advantageous / Here we are now, so fellate us / Roll it on now, lubricate us / Get us off now, ejaculate us." ${ }^{12}$ Therefore it can be argued that such intentionally ambivalent signification - or "anarchy of signification", ${ }^{30}$ as Judith "Jack" Halberstam has it - is a significant feature of queer-feminist punk as such.

The meanings of music, though, as musicologists like Philip Tagg ${ }^{31}$ argue, is never sufficiently covered by lyrics alone. Rather, sound, rhythm and artistic expression need to be considered, to fully analyze them. Furthermore, these meanings must not be reduced to political ideologies or any other intentional messages. Affective experience is a part of every performance, every reception of music, as well as every writing and reading process. The affective experience cannot be detached from the meaning of the product, no matter if written, recorded or performed live. As Tagg and other researchers have pointed out, "the relationship of words to music in rock is not simply the setting of words to appropriate music, but the fusion of words and vocal gestures into musical signs comprised of an indissoluble alloy of both." ${ }^{32}$ Following Simon Frith's work, they understand that

[s]ong words work as speech and speech acts, bearing meaning not just semantically, but also as structures of sound that are direct signs of emotion and marks of character. Singers use non-verbal as well as verbal devices to make their points - emphases, sighs, hesitations, changes of tone; lyrics involve pleas, sneers and commands as well as statements and messages and stories (which is why some singers, such as the Beatles and Bob Dylan in Europe in the sixties, can have profound significance for listeners who do not understand a word they are singing). 33

Transposition, 3 | 2013 

and the (physical) experience of queer-feminist punk rock. Looking at the bodies that perform punk music, scholars - from the first punk researcher Dick Hebdige to recent queer-feminist theorist Michelle Habell-Pallán - have suggested that the most prominent connotation that punk rock as aesthetic form or genre carries within mainstream as well as counter-cultural spheres, besides rebellion and rejection, is anger. In an interview conducted by scholar Michelle Habell-Pallán, Alice Armendariz Velasquez, one of Los Angeles' very first punk musicians, confirms theorists connection of punk with anger, describing her musical performances in the following way:

all the violence that I'd stuffed down inside of me for years came screaming out ... all the anger I felt towards people who had treated me like an idiot as a young girl because I was the daughter of Mexican parents and spoke broken English, all the times I'd been picked on by peers because I was overweight and wore glasses, all the impotent rage that I had towards my father for beating my mother just exploded..$^{34}$

Alice Armendariz Velasquez emphasizes the personal and physical qualities of anger, as well as the function of angry expressions for letting off steam. Feminist analysis of emotions $^{35}$ or anger, ${ }^{36}$ on the other hand, have emphasized that the articulation of 
emotion can have a political potential. It can be argued that the initial reasons for Armendariz Velasquez' anger as well as her performance of anger were political. However, although anger can be used as political activism and agency, such anger needs to be conscious and reflected in order to be politically productive. Nevertheless, as Armendariz Velasquez indicates, anger is always also a very bodily experience. Feminist Audre Lorde, for example, explained the bodily implications and expressions very vividly in her book Sister Outsider. A focus on anger, as an emotion as well as an experience, might be useful to further investigate the politics of negativity within contemporary queerfeminist punk rock.

\section{Punk as a form of political anger. The connection between Queerness, Negativity and Anger}

Expressions of anger within queer-feminist punk rock are mostly retroactively staged and well reflected, because they are not spontaneous. What causes those forms of anger lies in the past or in a general reflection on oppression. Saying that punk's anger is staged does not mean that it is not felt in the moment of expression. It rather means that the anger is felt (again) purposely. Furthermore, such experiences of anger are, most importantly, enjoyed. Expressions and performances of anger within punk are forms of enjoyment which come very close to what psychoanalytical theorists have called jouissance, "the painful pleasure of exceeding a law in which we were implicated, an enjoyment of a desire (desir), in the mode of rage or grief, that is the cause and result of refusing to be disciplined by the body hanging from the gallows of the law", as Elizabeth Povinelli has described it. In the case of punk rock the law Povinelli mentions are social rules and structures. The expressions of anger, angry lyrics, angry voices, or angry music, exceed these rules and norms insofar as they violate them. Examples of such violations are breaking taboos, like screaming angrily in public, using offensive language intentionally, etc.

As I have already shown, considering queer-feminist punk rock's politics as anger, first of all, requires a perspective on anger as a legitimate form of political articulation. If anger is understood as form of politics, such politics exceed the level of language. Anger is a bodily expression and reflection of, as well as reaction to, experience. It is always at the intersection of the body, the mind and the social. In fact the angry articulation - the screaming, the violent movements of the body and the fast sound - should be understood as political as such. Furthermore, not only the production of queer-feminist punk is political, but also the experience of it, no matter whether the shouted lyrics are understood or not. This, of course, does not mean that verbal communication, lyrics and other spoken or written forms of language are not key to the politics of queer-feminist punk. Thus, they are not the only meaningful factor. A consideration of anger is helpful to understanding how queer-feminist punk politics operate. Anger, as Sarah Ahmed ${ }^{37}$ has pointed out, rests on the very intersection of the body, the mind and social experience. Moreover, emotions connect the body with language and meaning. 


\section{Screaming as jouissance - on the relation of psyche and the body}

How tight the connection between emotions (or the body) and language is, can be seen in language's actual manifestation through the voice. The voice is a medium that connects the body to language and society. It is in the voice that the body becomes noticeable, through intonation, tempo and individual sound, and meaningful language becomes communicated. Thus, the voice is never authentic or genuine, ${ }^{38}$ because it is always formed by society as its purpose is social communication. Nevertheless, physical speech, like musical expression, especially through the voice, is a form of agency.

Lacan clearly distinguishes language and the symbolic from the body. He frames language as preexisting speech and the body who articulates. Language, further following Lacan, determines its own articulations as well as the subject that articulates it. As feminist theorists have argued, although the experience and the self's concept of body is always already constructed by and mediated through language and the symbolic, it is never fully so. Julia Kristeva argues in her text "Revolution in Poetic Language and Desire in Language", that what could be called a bodily rest can be found in the poetic voice. What Kristeva calls the "maternal body", "cannot be reduced to either a naturalistic conception of embodiment that escapes cultural inscription or to a human cultural construction like so many others. The maternal body, the semiotic chora, is actually the place of this split." ${ }^{39}$ This rest can be understood as materiality as well as an interrupting force. It is jouissance, the force that moves the Lacanian subject back and forth "between being and knowing, between drive and desire." ${ }^{40}$ Kristeva's account, as Nehring has observed, allows for an understanding of the voice as "exceeding rational meaning through a tactile 'grain' and jouissance [...] or a corporeal significance." ${ }^{41}$ Although Kristeva's account adjudicates bodily expression, like the voice, a political value, it only does so by detaching it from the act of producing meaning consciously. ${ }^{42}$ The embodied voice's meaning accordingly is detached from the subject's intention.

In the concrete example of the queer-feminist punk singer, this would indicate, that the vocal utterance's meaning and effect, are entirely detached from the intention of the individual, involuntarily, that the utterance is therefore useless as means of political agency. Contrary to this view, experience within queer-feminist punk subcultures as well as prior theoretical analysis ${ }^{43}$ established that queer-feminist punk music and writing must be seen as 'successful' political activism.

Combining psychoanalytical accounts of the voice with theories of anger allows us to understand the interruptive force of angry music as both conscious and at the same time exceeding the symbolic as well as consciousness. Accordingly, it can be argued, that the negative emotions in punk music and writing, the celebration of anger and sarcasm, as well as the fast and edgy sound are a conscious politics of negativity. At the same time as they are conscious, they go beyond the mind. The experience results in politics with the potential of irritating hegemony, and paradoxically results in feelings of communality or community. The communities created through such queer bonds in this a setting are felt rather than structural, or exceed the structural limits. This fact deserves some attention because it also means that such bonds exceed the limits of verbal expression and therefore the limits of labels and categories. Understood as a political tactic, angry punk 
rock accordingly has the potential to connect people, ideas and efforts beyond a necessary identification or group affiliations.

The potential of queer-feminist punk's anger and negativity can be best illustrated by framing it around the physical activity of screaming. Screaming in punk rock, punk rock researchers agree, has a meaning beyond the delivering of lyrics. To a degree screaming is pleasure for the singer, but moreover, especially for women and other subordinated groups, it is negativity. This negativity lies most obviously in the violation of norms and rules. Although it has to be admitted that punk's screaming has become a norm for punk performance itself, since the beginning of punk in 1976, the meaning of screaming, as a violation of norms, is still present. Furthermore the sound of punk occasionally offends "the norms" quite literally, when residents complain to the police about loud noises. Analyzing a concrete performance by the band Stag Bitten, I will further concretize features of queer-feminist punk politics.

\section{Screams: The voice, the body, and meaning}

Stag Bitten is a hardcore punk band from Portland, Oregon, that frequently performs in queer-feminist punk and queer punks of color contexts. Their presence on the Internet as well as in pertinent publications is very minimal. Their LastFM description does not indicate their sexual self-identification or politics. Declaring that they believe in d.i.y. ethics, and therefore self-release their CDs and cassettes, they do not offer any other indication of their politics in any self-description. In fact, no verbal expression of Stag Bitten's politics is recorded at all. During their concerts they do not speak to the audience, at least not during the concerts I participated in, and their lyrics are articulated or performed in a way that makes them incomprehensible.

Despite this lack of information, it can be argued that Stag Bitten fosters queer-feminist as well as anti-racist and decolonization politics. Flyers and other announcements for their shows have phrases like "support brown punx", and they perform in lineups with bands known for their queer-feminist decolonial politics. Most obviously the members of Stag Bitten show queer-feminist politics, however, when performing under the name Negro Nation. Interestingly, they use this name only when covering other bands' songs. The name Negro Nation can be read as reference to political accounts by people of color like Chicano Nation or African nationalism. African nationalism, also called black nationalism, as well as Chicano/a nationalism reveals the continuation of colonialism in contemporary North America through the politics of multiculturalism. The critique of multiculturalism implicit in these performances is that the rhetoric of "unity" of state officials is the reiteration of the old mythology of 'the melting pot' of settler colonialism. This mythos tells that people of multiple heritages contributed equally to one North American culture - a culture that accepts everyone equally and grants every person equal opportunities. Such ideology ignores the violent history and continuation of exploitation, slavery and white supremacy. Although there are multiple indigenous nationalist philosophies, a common denominator is the advocacy for self-determination or independence from this continuation of European colonialism. Furthermore, these movements all foster confrontational and radical politics, less interested in a dialogue with what they understand as the ruling white hegemony than in revolution and liberation. 
Stag Bitten, by using the pseudonym Negro Nation, refers to the historic and contemporary colonialism within the United States. Moreover, by playing cover songs from the most popular white punk and grunge bands like Crass, and Nirvana, among others, they criticize left punk scenes' white boy dominance. By choosing Crass' song "Shaved Women" and Nirvana's "Territorial Pissing" they, additionally seem to render ironic punk's attempts to fight misogyny. Beyond their usage of the pseudonym Negro Nation, Stag Bitten's politics can be seen in the places and line-ups they choose. They regularly perform in line-ups with bands like NO/HO/MO, NighTraiN or MyParade who are vocal about their queer-feminist and or queer people of color politics. Furthermore, they play events with very distinct queer-feminist people of color politics. The Stag Bitten performance that will be analyzed in the following was supporting exactly such a queerfeminist people of color effort.

Stag Bitten played in a set with NighTraiN, MyParade, and Kusikia, three bands that all include or consist entirely of queer people of color, at the feminist bookstore In Other Words in Portland, OR on August, 28th 2010. The event was a release party for the fifth issue of Oza Atoe's queer punks of color zine Shotgun Seamstress. The most interesting feature of Stag Bitten is the presence of their vocalist Arolia McSwain. McSwain, who identifies as punk of color, according to the promotion material for her shows, performed every single song of their set in a very high energy, intense way, screaming and shouting from the top of her lungs. It can be argued that it is her stage presence that made a commentator describe the band as a "power trio that snarls like Cerberus at the gates of the underworld." ${ }^{44}$ The experience of McSwain's strong, sharp and loud voice, is further intensified by her bodily movements and her facial expression. Her whole body communicates intense emotions - rage and anger, so it seems, but also a lot of pleasure. During every song she seems detached from the place, in a stage of agitation. It is exactly the word 'drive' or force that describes McSwain's performance best. Yet she clearly remains connected to her fellow band mates, who provide the beats and melodies to her screams and additionally makes a strong connection to her audience. The audience seemed fascinated by her outburst, and drawn into her world, some even seem to participate in her drive. McSwain seemed to consciously lead the crowd, paradoxically through her own state of loosing control.

The politics of such angry queer-feminist punk screams can be found on various levels. Screaming in public is, with a few exceptions, for instance in sport arenas, understood as disturbing and inappropriate, vulgar and a marker of a low social status. While a screaming man is mostly associated with danger, screaming by female identified or feminine acting persons is frequently associated with vulnerability. Joanna Gottlieb and Gayle Wald label feminine screams as "emotional ejaculations", 45 associated with violence, or with very messy and private events like childbirth or orgasm. Female and feminine screams are highly sanctioned expressions, devalued in public as well as in private.

41 Often associated with femininity at its most vulnerable, the scream in its punk context can effect a shocking juxtaposition of sex and rage, including the cultural terrors of the open expressions of female sexuality, or feminist rage at the sexual uses and abuses of women. If female screams are often associated with women's sexual violation and rape, then these examples seem to voice a collective outrage at such abuse. ${ }^{46}$

In other words, the appropriation of punk rock as a form of musical screaming by femaleidentified persons can be understood as a rejection and appropriation of socio-cultural 
stereotypes. It can be understood as problematizing sex, gender as well as sexuality. Moreover, punk screams can be read as reference to sexual acts. Additionally, it can be argued, queer-feminist punk screams do not only signify sexuality on the level of criticism, as indicated by Wald and Gottlieb, but rather imitate sexuality in its most negative stage.

That such an understanding of punk music is indeed collectively shared throughout punk scenes can be seen in reports about punk concerts by punks themselves. In a recent issue of the Maximumrocknroll column "Bryony Beynon gives it to you straight", the author described his/her punk music experience as "Concussion in place of orgasm. Safer, littler deaths." ${ }^{47}$ Wald's and Gottlieb's estimation about queer female punk screams can be argued for people of colors' punk screams as well. Although the socio-cultural discourses around people of color and screaming are very different than around white women, nonwhites are both signified as screamers and excluded from socially acceptable forms of screaming, or any other form of angry articulation, as Lorde and many others have shown. Therefore, performances of screaming, as in the example of McSwain, can be understood as a rejection of the prohibition to scream. It is a violation of gender norms, because she identifies or becomes identified as a woman, as well as class norms, because only lower classes are associated with screaming, as well as racialized norms. At the same time, it is also an appropriation of stereotypes, because women are associated with screaming (and emotionality in general in certain contexts) and so are people of color. Her punk screams address violence against women and people of color, and at the same time function as a sign of strength and agency.

Moreover, through the scream's sensual quality, the screamer's bodily presence and the sound, it is able to establish relations between the singer and the audience. Besides the irritating and violent potential of punk anger, however, the music potentially also establishes queer bonds.

\section{Conclusion}

The examples of queer punk rock and punk writing discussed in this article illustrate forms of queer-feminist activism and agency. They need to be understood as adaptations, combinations and creative reworkings of queer theory as well as feminist philosophy. The cultural, political and aesthetic mode of queer-feminist punk rock is negativity and anger. Provided that punk rock can be understood as politics, it can be argued that punk music is a politics of negativity and anger. Located within the sphere of meaning and verbal expression, punk's politics of anger communicates social criticism; however, this anger can be perceptible not only on the level of verbal expressions, but additionally within music, sound and bodily expressions. Using work on emotions and emotionality I was able to show that the politics of anger and negativity operate forcefully at the intersection between rational, emotional and bodily cognition and meanings.

Bands such as Tribe 8, Agatha, Pansy Division, or Stag Bitten use the genre of queercore to communicate their queer-feminist positions and critique - a critique which reflects discussions within queer and feminist theory as well as everyday experience and practice. Moreover, it can be argued that queercore, through the pleasurable media of music and do-it-yourself publications, is able to communicate queer theory's complex and often complicated approaches in a non-academic setting to a (largely) non-academic audience. 
47 It has become clear why the concept of punk, with its tradition of expressing anger, its fast rhythms, screaming, and simplicity, is a perfect means to communicate queerfeminist agendas. By analyzing some songs, queer-feminist punk music and writings, it has also become clear that queercore does not exclusively focus on oppression based on sexual deviance. By addressing a whole variety of identity-categories in an intersectional mode, queercore manages to make oppressive social structures and norms of social interaction visible. In doing so, its agendas can be meaningfully interpreted as being closely connected to the queer movements as well as to earlier forms of feminist movements, while at the same time focusing attention on their blind spots and transgressing their limits.

Through their thematic but also social affiliations to feminist groups and movements, their critique of norms and power structures reaches not only punk and queer environments but also feminist and/or lesbian subcultures and people of color communities. Through their critical stance towards practices and values within hardcore, as well as gay and lesbian scenes, they challenge the worldview that dominates these scenes and continue a queer-feminist dialogue.

\section{BIBLIOGRAPHY}

BEEBER, Steven Lee, The Heebie - Jeebies at CBGB's: A Secret History of Jewish Punk, Chicago, Chicago Review Press, 2006.

BEYNON, Bryony, "Bryony Beynon Gives It To You Straight", in Maximumrocknroll, № 345, February 2012.

CAMERON, Ed, "Severing Sound from Sense: The Sacrifice of Drive in Butler's Critique of Kristeva", in Women Writers: A Zine, Home page. 1 January 2010. http://www.womenwriters.net/ index.html

DRIVER, Susan (ed.), Queer Youth Cultures, Albany, State University of New York Press, 2008.

DUPLESSIS, Michael and CHAPMAN, "Queercore: The Distinct Identities of Subculture", in College Literature, Vol. 24, № 1, 1997, p. 45-58.

DUGGAN, Lisa, "Making it Perfectly Queer", in Socialist Review, Vol. 22, № 1, 1992, p. 11-31.

DYNES, Wayne, "Queer", in Encyclopedia of Homosexuality, New York, Garland, 1990.

EDELMAN, Lee, No Future. Queer Theory and the Death Drive, Durham,London, Duke University Press, 2004.

FLANNIGAN, Tracy, Rise Above: A Tribe 8 Documentary, Los Angeles: LILITH SIMCOX, 2003.

FORD, Phil, "Hip Sensibility in an Age of Mass Counterculture", in Jazz Perspectives, Vol. 2, № 2, 2008, p. 121-163.

FRITH, Simon, Why music matters. Critical Quarterly, Vol. 50 № 1-2, Spring/Summer 2008, p. 165179. 
GINOLI, Jon, Deflowered: My Life in Pansy Division, California, Cleis Press, 2009.

GOTTLIEB, Joanne, and WALD, Gayle, "Smells Like Teen Spirit: Riot Grrrls Revolution and Women in Independent Rock", in ROSS, Andrew and ROSE, Tricia (eds.), Microphone Fiends: Youth Music and Youth Culture, New York, Routledge, 1994, p. 250-274.

HABELL-PALLÁN, Michelle, "Soy Punkera, y Qué ?", in DUNCOMBE, Stephen and TREMBLAY, Tremblay (ed.), White Riot: Punk Rock and the Politics of Race, London, Verso, 2011, p. 222-230.

HALBERSTAM, Judith, Female Masculinity, Durham, London, Duke University Press, 1998.

HALBERSTAM, Judith, In a Queer Time and Place: Transgender Bodies, Subcultural Lives, New York, London, New York University Press, 2005.

HALBERSTAM, Judith, "The Politics of Negativity in Recent Queer Theory", in Publication of the Modern Language Association of America, Vol. 121, № 3, May 2006, p. 823-825.

HALBERSTAM, Judith, "The Anti-Social Turn in Queer Studies", in Graduate Journal of Social Science, Vol. 5, Issue 2, 2008, p. 140-156.

HALBERSTAM, Judith, The Queer Art of Failure, Durham, London, Duke University Press, 2011.

JUNO, Andrea and VALE, Vivian (eds.), Angry Women, San Francisco, Re/Search Publications, 1991.

KAPLAN, Esther, "A Queer Manifesto", in Village Voice, 14 August 1992, p. 36.

MARCUS, Sara, Girls to the Front: The True Story of the Riot Grrrl Revolution, New York, London, Toronto, Harper Perennial, 2010.

LABRUCE, Bruce and JONES, J.B. "Don't be gay: Or, how I learned to stop worrying and fuck punk up the ass", in Maximumrocknroll, April 1989, p. 27-30.

LORDE, Audre, Sister Outsider, Berkeley, Crossing Press, 1984.

MUÑOZ, Jose, Disidentifications: Queers Of Color And The Performance Of Politics, Minneapolis, University of Minnesota Press, 1999.

MUÑOZ, Jose, Cruising Utopia: The Then and There of Queer Futurity, New York, London, New York University Press, 2009.

NYONG'O, Tavia, "Do You Want Queer Theory (or Do You Want the Truth)? Intersections of Punk and Queer in the 1970s", in Radical History Review, Vol. 2008, № 100, 2008, p. 103-119.

RITCHIE, Neal, "Principles of Engagement. The Anarchist Influence on Queer Youth Cultures", in DRIVER, Susan (ed.), Queer Youth Cultures, Albany, State University of New York Press, 2008, p. 261-278.

SEDGWICK, Eve Kosofsky, Tendencies, Durham, Duke University Press, 2006.

SPENCER, Amy, DIY: The Rise of Lo-Fi Culture, London, New York, Marion Boyars, 2008.

TAGG, Philip, "Analysing popular music: theory, method and practice", in Popular Music, Vol. 2, 1982, p. 37-65.

WALES, Aris, Nasalrod, Stag Bitten, Big Black Cloud, Review, 15 June 2011, http:// endhits.portlandmercury.com/endhits/archives/2011/06/15/tonight-in-music-grouper-stagbitten-jason-isbell-and-more

WILSON, Angela, "The Galaxy Is Gay: Examining The Networks of Lesbian Punk Rock Subculture", in DRIVER, Susan (ed.), Queer Youth Cultures, Albany, State University of New York Press, 2008, p. 51-68. 
WOBENSMITH, Matt, "R.I.P. 1992-1997", in Outpunk, № 7, 1997, p. 1.

\section{Sound recording reference}

Agatha, Queer as in Fuck You, Agatha, Rumbletowne Records, "Panic Attack".

Tribe 8, Neanderthaldyke, Tribe 8, Alternative Tentacles, "Fist City".

Tribe 8, People Hate Me, Tribe 8, Alternative Tentacles, "Snarkism".

Jon Ginoli, Smell's like queer spirit, Pansy Division, "Pansy Division Live 1992-2003".

\section{NOTES}

1. This text is based on the author's ongoing Ph.D project.

2. MUÑOZ, José, Disidentifications: Queers of Color And The Performance of Politics, Minneapolis, University of Minnesota Press, 1999; MUÑOZ, José, Cruising Utopia: The Then and There of Queer Futurity, New York, London, New York University Press, 2009.

3. HALBERSTAM, Judith, In a Queer Time and Place: Transgender Bodies, Subcultural Lives, New York, London, New York University Press, 2005; HALBERSTAM, Judith, "The Anti-Social Turn in Queer Studies", in Graduate Journal of Social Science, Vol. 5, Issue 2, 2008, p. 140-156; HALBERSTAM, Judith, The Queer Art of Failure, Durham, London, Duke University Press, 2011.

4. HALBERSTAM, Judith, In a Queer Time and Place: Transgender Bodies, Subcultural Lives, op. cit.; HALBERSTAM, Judith, "The Anti-Social Turn in Queer Studies", op. cit.

5. MUÑOZ, José, Disidentifications: Queers of Color And The Performance of Politics, op. cit.; MUÑOZ, José, Cruising Utopia: The Then and There of Queer Futurity, op. cit.

6. WILSON, Angela, "The Galaxy Is Gay: Examining The Networks of Lesbian Punk Rock Subculture", in DRIVER, Susan (ed.). Queer Youth Cultures, Albany, State University of New York Press, 2008, p. 51-68.

7. LABRUCE, Bruce, JONES, J.B., "Don't be gay: Or, how I learned to stop worrying and fuck punk up the ass", in Maximumrocknroll, April 1989, p. 27-30.

8. God Is My Co-Pilot - probably named after the 1945 American propaganda film based on the autobiography of Robert Lee Scott, Jr., a United States Army Air Forces pilot during World War II. - started playing in New York City in 1990. Constant members and masterminds of the band were vocalist Sharon Topper and Craig Flanagin on guitar. They played with a varying set of other New York based musicians such as Fly, Daria Klotz, John Zorn, Jad Fair, Fredrik Haake and others. They played at New York's most popular indie and punk locations like the still existing Mercury Lounge, in line ups with other popular queer punk performers like Vaginal Davis. Their lyrics almost exclusively addressed themes of sexuality and gender, most of them in English with occasional lines in French, Yiddish, German, Finnish, and Turkish, among others. Their creative work between 1991 and 1999 encompasses quite an impressive amount of releases, more than 15 full-length albums, many singles, a compilation and quite a few zines.

9. SEDGWICK, Eve Kosofsky, Tendencies, Durham, Duke University Press, 2006, p. 8. 
10. RITCHIE, Neal, "Principles of Engagement. The Anarchist Influence on Queer Youth Cultures", in DRIVER, Susan (ed.), op. cit., p. 270.

11. HALBERSTAM, Judith, "The Anti-Social Turn in Queer Studies", op. cit., p. 140-156.

12. BERSANI, Leo quoted in HALBERSTAM, Judith, ibid., p. 140.

13. BERSANI, Leo quoted in HALBERSTAM, Judith, "The Politics of Negativity in Recent Queer Theory", in Publication of the Modern Language Association of America, Vol. 121, № 3 , May 2006, p. 823.

14. EDELMAN, Lee. No Future. Queer Theory and the Death Drive, Durham, London, Duke University Press, 2004, p. 3.

15. Ibid.

16. HALBERSTAM, Judith, "The Politics of Negativity in Recent Queer Theory", op. cit., p. 823.

17. EDELMAN, Lee, op. cit., p. 29.

18. MUÑOZ, José, Disidentifications: Queers of Color And The Performance Of Politics, op. cit.

19. NYONG'O, Tavia, "Do You Want Queer Theory (or Do You Want the Truth)? Intersections of Punk and Queer in the 1970s", in Radical History Review, Vol. 2008, № 100, 2008, p. 103-119.

20. BEEBER, Steven Lee, The Heebie - Jeebies at CBGB's: A Secret History of Jewish Punk, Chicago, Chicago Review Press, 2006, p. 8.

21. Agatha, Queer as in Fuck You, Agatha, Rumbletowne Records, "Panic Attack".

22. DYNES, Wayne, "Queer", in Encyclopedia of Homosexuality, New York, Garland, 1990, p. 191.

23. KAPLAN, Esther, "A Queer Manifesto", in Village Voice, 14 August 1992, p. 36.

24. DUGGAN, Lisa, "Making it Perfectly Queer", in Socialist Review, Vol. 22, № 1, 1992, p. 16.

25. Named after the sexual practice of tribadism, Tribe 8 formed in 1990 and was a lesbian-only band from San Francisco, California. Today, the band is considered to be crucial for the development of queercore. The former band members, especially former singer Lynn Breedlove, who became a popular comedian and novelist, have the status of cult figures and role models and are known in queer scenes all over the world. Until its official break-up in 2005, the band included singer Lynn Breedlove, guitarists Leslie Mah and Lynn Flipper, Slade Bellum on the Drums, Jen Rampage, Mama T and Tantrum on the bass. They mostly toured through the United States but occasionally played a few gigs in Europe and Canada.

26. The Michigan Womyn's Music Festival is an feminist women-only music festival occurring every August since 1976 near Hart, Michigan. The festivals policy to allow only cis-gendered women onto the festival grounds, is a constant point of critique within feminist scenes and beyond. Since 1991, when a transgendered person was dispersed from festival grounds, queer, and transgender activists challenge the festival with their protest, asking for a dialogue on the festivals rigid binary sex- and gender-concepts.

27. Agatha, Queer as in Fuck You, Agatha, Rumbletowne Records, "Panic Attack".

28. Pansy Division was a pop-punk band founded by Jon Ginoli, in San Francisco in 1989. "[F]orming Pansy Division was my way of doing activism", Ginoli recalls in his autobiography Deflowered (GINOLI, Jon, Deflowered: My Life in Pansy Division, California, Cleis Press, 2009 p. 27). In 1994 they reached mainstream publicity when they toured with 
Green Day. In 1996 drummer Luis Illades joined the band, followed by guitarist Joel Reader in 2004. Pansy Division always stayed true to their queer and d.i.y. principles. Their music, although it clearly emphasized fun over punk rage and anger, always had a political and educational purpose. On their album Deflowered for example they released a list of contact addresses of gay youth groups around the US. All four band members fostered queer-feminist punk far beyond their band project and continue to support current efforts.

29. Jon Ginoli, Smell's like queer spirit, Pansy Division, "Pansy Division Live 1992-2003".

30. HALBERSTAM, Judith, "The Anti-Social Turn in Queer Studies", op. cit., p. 149.

31. TAGG, Philip, "Analysing popular music: theory, method and practice", in Popular Music, Vol. 2, 1982, p. 37-65.

32. FORD, Phil, "Hip Sensibility in an Age of Mass Counterculture", in Jazz Perspectives, Vol. 2, № 2, 2008, p. 160.

33. FRITH, Simon, "Why music matters", in Critical Quarterly, Vol. 50, № 1-2, Spring/ Summer 2008, p. 170.

34. ARMENDARIZ VELASQUEZ, Alice quoted in HABELL-PALLÁN, Michelle, "Soy Punkera, y Qué ?", in DUNCOMBE, Stephen, MAXWELL, Tremblay (eds.), White Riot: Punk Rock and the Politics of Race, London, Verso 2011, p. 226.

35. AHMED, Sara, The Cultural Politics of Emotion, New York, Routledge, 2004.

36. LORDE, Audre, Sister Outsider, Berkeley, Crossing Press, 1984; NEHRIN, Neil, Popular Music, Gender, and Postmodernism: Anger is an Energy, Thousand Oaks, London, New Delhi, Sage Publications, 1997.

37. AHMED, Sara, op. cit., p. 175.

38. NEHRIN, Neil, op. cit., p. 133.

39. KRISTEVA, Julia quoted in CAMERON, Ed, "Severing Sound from Sense: The Sacrifice of Drive in Butler's Critique of Kristeva", in Women Writers: A Zine, Home page. 1 January 2010. http://www.womenwriters.net/index.html

40. Ibid.

41. KRISTEVA, Julia quoted in NEHRIN, Neil, op. cit., p. 131.

42. CAMERON, Ed, "Severing Sound from Sense: The Sacrifice of Drive in Butler's Critique of Kristeva", op. cit. http://www.womenwriters.net/index.html

43. HALBERSTAM, Judith, In a Queer Time and Place: Transgender Bodies, Subcultural Lives, op. cit.; MUÑOZ, José, Disidentifications: Queers of Color And The Performance of Politics, op. cit., and id., Cruising Utopia: The Then and There of Queer Futurity, op. cit.; DRIVER, Susan (ed.), op. cit.; MARCUS, Sara, Girls to the Front: The True Story of the Riot Grrrl Revolution, New York, London, Toronto, Harper Perennial, 2010.

44. WALES, Aris, Nasalrod, Stag Bitten, Big Black Cloud, Review, 15 June 2011.

45. GOTTLIEB, Joanne, and WALD, Gayle, "Smells Like Teen Spirit: Riot Grrrls, Revolution and Women in Independent Rock", in ROSS, Andrew and ROSE, Tricia (ed.), Microphone Fiends: Youth Music and Youth Culture, New York, Routledge, 1994, p. 261.

46. Ibid.

47. BEYNON, Bryony, "Bryony Beynon Gives It To You Straight", in Maximumrocknroll, № 345, February 2012. 


\section{ABSTRACTS}

This article focuses on queer-feminist punk, also known as queercore, homocore or dykecore. It presents some examples of punk rock performers and their cultural productions (Tribe 8, Agatha, Stag Bitten and others) to argue that these bands produce countercultural and alternative forms of queer politics and queer theory as well as feminist theory. Moreover, such queer politics are understood as a continuation of feminist movements and theory. Queer-feminist punk activists participate in a dialogue with other feminist and queer movements to build alliances and forms of solidarity to resists the - often racialized - misogyny of mainstream culture as well as countercultural environments. They combine feminist accounts with their specific punk philosophy of anti-social queerness or queer negativity. Analyzing lyrical content - its meanings, its rhetoric, or tone - it will be shown that queer-feminist punk music uses the term queer as anti-identitarian and anti-social. Their discourses on queerness parallel in interesting ways antirelational queer theory, for example by Lee Edelman, who understands queerness as a negative force in sexuality that irritates a subject's psychic coherence and is therefore unable to support social relations. To account for the decolonial and anti-racist aspects of queer-feminist punk rock anti-social queer theories will be combined and extended by works by the black feminists bell hooks and Audre Lorde. The black feminists' theorization of anger allows for a thinking through of the anti-social and queer at the intersection of racialization. Moreover, focusing anger allows to analyze anti-social queer politics beyond the realm of symbolic meaning: to focus action, feelings, experience and the body.

Cet article analyse le punk queer-féministe, connu aussi sous les noms de queercore, homocore ou dykecore. Il présente quelques exemples de performers punk rock (Tribe 8, Agatha, Stag Bitten) et de leurs productions culturelles, pour démontrer que ces groupes produisent des formes contreculturelles et alternatives de la politique et théorie queer autant que de la théorie féministe. De plus, de telles politiques queer sont comprises comme le prolongement du mouvement et de la théorie féministes. Les activistes punk queer-féministes participent d'un dialogue avec les autres mouvements féministes pour bâtir des alliances et des formes de solidarité afin de résister à la misogynie - souvent racialisée - de la culture mainstream autant que des environnements contreculturels. Ils associent des considérations féministes à leur philosophie particulière punk, qui est une philosophie de la négativité et de l'anti-socialité queer. Par l'analyse du contenu des paroles leur signification, leur rhétorique ou leur ton - il s'agira de montrer que la musique punk queerféministe utilise le terme «queer » en tant qu'anti-identitaire et anti-social. Leurs discours sur l'être queer sont, de façon intéressante, comparables à la théorie queer anti-relationnelle, par exemple celle de Lee Edelman comprenant l'être queer comme une force négative dans la sexualité, qui contrarie la cohérence psychique du sujet et qui par conséquent empêche d'établir des relations sociales. Pour répondre aux aspects dé-coloniaux et anti-racistes du punk rock féministe, les théories queer anti-sociales seront prolongées par les travaux des féministes noires bell hooks et Audre Lorde. La théorisation de la colère par les féministes noires tient compte d'une réflexion sérieuse de l'anti-social et du queer au croisement de la racialisation. De plus, axer sur la colère permet d'analyser la politique queer anti-sociale au-delà du domaine de la signification symbolique : se centrer sur l'action, les sentiments, l'expérience et le corps. 


\section{INDEX}

Mots-clés: théorie antisociale, théorie féministe, politiques de la négativité, négativité queer, activisme, théorie queer, Agatha, dykecore, homocore, Pansy Division, queercore, Stag Bitten, Tribe 8

Keywords: anti-social theory, feminist theory, politics of negativity, queer negativity, activism, queer theory, Agatha, dykecore, homocore, Pansy Division, queercore, Stag Bitten, Tribe 8

\section{AUTHOR}

\section{MARIA KATHARINA WIEDLACK}

Maria Katharina Wiedlack is PhD candidate at the department of English, University of Vienna. She currently works at the Gender Research Office at the University of Vienna. For her dissertation, she is working on the topic of punk rock, anti-social queer theory and countercultural activism. Her research interests include anarchist, feminist and queer theory, decolonial, as well as disability studies. Besides her professional work that included the organization of and participation in multiple queer conferences in Vienna and beyond, she participates in radical queer-feminist activism in Vienna and the US context. 